\title{
TP53INP1 wt Allele
}

National Cancer Institute

\section{Source}

National Cancer Institute. TP53INP1 wt Allele. NCI Thesaurus. Code C92491.

Human TP53INP1 wild-type allele is located in the vicinity of 8q22 and is approximately $23 \mathrm{~kb}$ in length. This allele, which encodes tumor protein p53-inducible nuclear protein 1, is involved in the promotion of apoptosis in response to DNA damage. Aberrant expression of the gene is associated with pancreatic ductal adenocarcinomas and HTLV-related T cell leukemia. 